\title{
The Implementation of Corporate Branding and Social Responsibility of PT. Summarecon Agung Tbk Towards Social Welfare in North Bekasi Area
}

\author{
Andrian Andrian', Hadita Hadita ${ }^{2}$, Jumawan Jumawan ${ }^{3}$ \\ \{andriantahar@gmail.com¹, hadita.universitas@gmail.com²,jumawan@dsn.ubharajaya.ac.id ${ }^{3}$ \} \\ 1,2,3 Management Department, Faculty of Economic, Universitas Bhayangkara Jakarta Raya, Jl. Raya \\ Perjuangan No.1, Margamulya, Bekasi Utara, Kota Bekasi, Jawa Barat 17121, Indonesia.
}

\begin{abstract}
Corporate Branding refers to the practice of promoting the brand names of a corporate entity, as opposed to specific products of services. Also, Corporate Social Responsibility is a social program which has been applied by many companies in Indonesia. The implementation of Corporate Social Responsibility provides many benefits such as maintaining and enhancing the brand images of companies. This research aims at observing how far the implementation of the Corporate Branding and Social Responsibilities of PT. Summarecon Agung Tbk influences towards social welfare in North Bekasi Area. The indicators of welfare life are progress on health, education, and economic activity. This research concludes: corporate branding goal and corporate social responsibility's goal program of PT. Summarecon Agung Tbk have a positive effect on social life welfare in North Bekasi Area. The population in the research is the employees themselves (cq. Summarecon Bekasi) who know the Corporate Branding and Social Responsibilities' program applied by PT. Summarecon Agung Tbk company in Bekasi. The total sample used in the research is 100 persons of Summarecon Agung Bekasi unit's employees. The sampling technique in the research is purposive sampling and processed by Statistical Product for Social Science (SPSS) version 22. The result of the research indicates that the implementation of Corporate Branding and Social Responsibility influences positively the welfare of the society in Bekasi, especially North Bekasi area.
\end{abstract}

Keywords: Corporate Branding, Social Responsibility, Social Welfare, Brand Image, Purposive Sampling..

\section{Introduction}

PT. Summarecon Agung Tbk ("Summarecon") was founded in 1975 by Mr. Soetjipto Nagaria and his associates to undertake real estate construction and development. Starting with a 10-hectare of marshland in the then backwaters of Jakarta, the founders managed to transform Kelapa Gading into one of the most affluent residential and commercial areas in Jakarta.

And over the years Summarecon has built a reputation as one of the leading property players in Indonesia, especially in the development of townships. Summarecon develops townships which integrate residential developments with commercial developments that are supported with a wide and complete range of amenities for the resident of the townships. Summarecon has developed the expertise across the whole real estate values chain; encompassing development, architecture, engineering, project and construction management, 
urban planning, infrastructure, sustainable design technologies, town and neighborhood management, and property management, into the development of the township.

With an unparalleled combination of knowledge, execution skills, dedicated personnel and commitment to customers and suppliers as well, Summarecon is known for its dependability, expertise and ability to execute and deliver property development projects in Kelapa Gading, Serpong, Bekasi, Bandung and Karawang.

Summarecon's business units are grouped into three distinct activities :

- $\quad$ Property Development

- $\quad$ Property Investment and Management

- Leisure, Hospitality and Others

The purpose for this research is to analyze the implementation of the Corporate Branding and Social Responsibility of PT. Summarecon Agung Tbk, especially Summarecon Bekasi, towards social welfare for the society who lives in North Bekasi area. The researchers are interested in doing researches activity to know how far the empowerment and the role of PT. Summarecon Agung Tbk cq. Summarecon Bekasi against the North Bekasi society's living and lifestyle.

There are four mains reasons for conducting research. Firstly, research can contribute to the development of science. One good research can contribute to the development of science if: Closing exists gaps (address gaps in knowledge) in the developing science, by conducting research that less done in previous research. Replicating knowledge by examining the results of previous research based on the results of new research or examining the results of previous researches in the new research method. Expanding existing knowledge, which is expanding research on new ideas. Broaden perspectives by voicing groups of respondents and research subjects that voiceless. Secondly, research can also improve existing practices. In this context, research is conducted to provide various solutions and improvements offered by the results of these researches. Research always provides new inputs, suggestions and/or recommendations. Thirdly, the results of the research can also help policy-makers to formulate new policies for improvement. Fourthly, research can help communities / consumers to develop skills as a researcher in developing concepts, writing, and even organizing concepts. Research is not only useful in the context of developing theories, policies, and practices but also contributes to the birth of a new, more specific action to overcome certain problems [1]

The formulation of the problem in this research is: Does the implementation of Corporate Branding affect the social welfare in North Bekasi area and does the implementation of Social Responsibility affect the social welfare in North Bekasi area?

\section{Literature Review}

The following is presented several related theories relating to the activities of Corporate Branding, Social Responsibility and Social Welfare according to marketing experts.

\section{1. Theoretical Review}

Corporate Branding. Corporate Branding is another word from the Brand of a company, in which a characteristic or symbol that introduces a product or company to consumers. By the existence of corporate branding, consumers will be more familiar with the products that produced by the company. Corporate Branding also reflects what a company engaged in and with what kind of purpose, so that everything about the company will be incorporated in the reflection of a Corporate Branding.

Branding is a history of the marketing managers' responsibilities who have often limited access to the boardroom only. Classic management is primarily tasked by facilitating the 
relationship between customers and products, directing purchase differences, having emotional stress and communicating related brands such as advertising and promotion [2].

Branding management is directed to the potential of the customer, who is using advertising as the main meaning to attract attention and purchasing. Another concept of difference in branding management as functional differentiation is slowly disappeared, communication becomes the main source of differentiation (for example, creative advertising, embedding a product emotionally). The strategic goal of brand management is to encourage growth by creating a loyal customer base and generating opportunities for product extensions following popular brands. This is usually handled by brand management (at the product level) part of marketing team, often considered as a tactical task and therefore put in the middle-level management [3].

Social Responsibility. The definition of Corporate Social Responsibility or commonly abbreviated as CSR has been stated by many experts with different opinions. The most common definition and agreed upon by more than 90 countries worldwide is a definition according to ISO 26000. The definition of CSR according to ISO 26000 is Responsibility of an organization for the impacts of its decisions and activities on society and the environment, through transparent and ethical behavior that contributes to sustainable development, including health and the welfare of society; takes into accounting the expectations of stakeholder; is in compliance with applicable law and consistent with international norms of behavior; and is integrated throughout the organization and practiced in its relationship [4].

The definition above can be translated that an organization in taking every decision and carrying out its activities, must have called to the community and its environment which is manifested in a transparent form and ethical behavior which is in line with sustainable development, including health and welfare of the community; consider the expectations of stakeholders, which is in line with established laws and international behavioral norms; and integrated with the organization as a whole [4].

Whereas according to The World Bank Group and The World Business Council for Sustainable Development, CSR is defined as an ongoing commitment in business world to behave ethically and help sustainable development in collaboration with employees and their representatives, their families, communities, and the local community in general to renew the quality of life in good ways for business and development [5].

Social Welfare. Social welfare is an organized and systematic program that is equipped with all kinds of scientific skills, is a relatively developing new concept, especially in developing countries. Defining social welfare as follows: An organized system of institutional social services designed to help individuals and groups to achieve adequate living and health standards and personal and social relations to enable them to develop their abilities and social welfare fully align with the needs of the family and society [6].

\section{2. The Relationship between Corporate Branding and Social Responsibility with Social Welfare}

Industrialization requires mobilization of resources so that small or large, fast or slow can disrupt the balance of these resources. That is where the importance of sharing corporate social responsibility towards the environment and society, so that a balance of exploitation occurs (hereinafter referred to social responsibility). The definition shows that corporate social responsibility is a form of action that departs from the company's ethical considerations directed at improving the economy, coupled with improving the quality of life for employees and their families as well as improving the quality of life for surrounding communities and the wider community [7]. Legal responsibility is that companies must comply with the applicable 
legal rules, the minimum social requirements for corporate responsibility, and they need to include regulations in operational and management strategies, including obligations in manufacturing, consumption, and job security, and environmental protection, to avoid harming interested parties [8]. Ethical responsibility is a company whose core values and ideals must conform to moral norms in society, in accordance with social expectations or prohibitions to protect the rights and public interests of the interested parties [9].

\section{3. Thinking Framework and Hypothesis}

The increasing number of developers in Indonesia today, stimulates entrepreneurs to take part in this profitable business and being able to compete with other similar companies. And every company existence in the area, of course they also compete to be accepted by its existence in that environment. The presence of Summarecon Bekasi which is part of PT. Summarecon Agung Tbk, also prioritizes the welfare and empowerment of surrounding communities. The famous brand from Summarecon is a quality guarantee for property hunters and potential consumers, because the area developed by this company has always been an integrated area such as Kelapa Gading area in Jakarta and Serpong area in Tangerang. Besides that, its existence is always a benchmark for other developers and is also a pioneer in the development and progress of an area. The existence of Summarecon is also always a hope for job seekers to be able to improve their welfare. Thousands of Summarecon employees stepped in with one rhythm. They were given frames, asked to take seminars, and invited to other cities and see other companies. Summarecon applies the rules strictly, what is permissible or not. The company's culture was formed not in a month or two, but it took a relatively long time. The number of Summarecon employees spread in three locations, Kelapa Gading, Serpong, and Bekasi, reaching 3,000 must understand the company's culture.

The main indicators that shape the image of a brand are Brand Identity, Brand Personality, Brand Association, Brand Attitude and Behavior, and Brand Benefit and Competence [10]. Meanwhile, according to John Elkington through his book "Cannibals with Fork, the Triple Bottom Line of Twentieth Century Business" describes the forming indicators of Social Responsibility. Elkington develops the triple bottom line concept in terms of economic prosperity, environmental quality and social justice. Elkington gives the view that companies that want to be sustainable must pay attention to "3P". In addition to pursuing profits, companies must also pay attention and be involved in fulfilling people's welfare (people) and contribute actively in preserving the environment (planet) [11]. These indicators then synergize with the indicators of Social Welfare, which includes three basic conceptions, namely: (1) Living conditions or prosperity, namely the fulfillment of physical, spiritual and social needs; (2) Institutions, arenas or fields of activity involving social welfare institutions and various humanitarian professions that carry out social welfare businesses and social services; (3) Activities, namely an organized activity or effort to achieve prosperous conditions [12].

Based on the above explanation, the picture of the theoretical framework is as follows: 


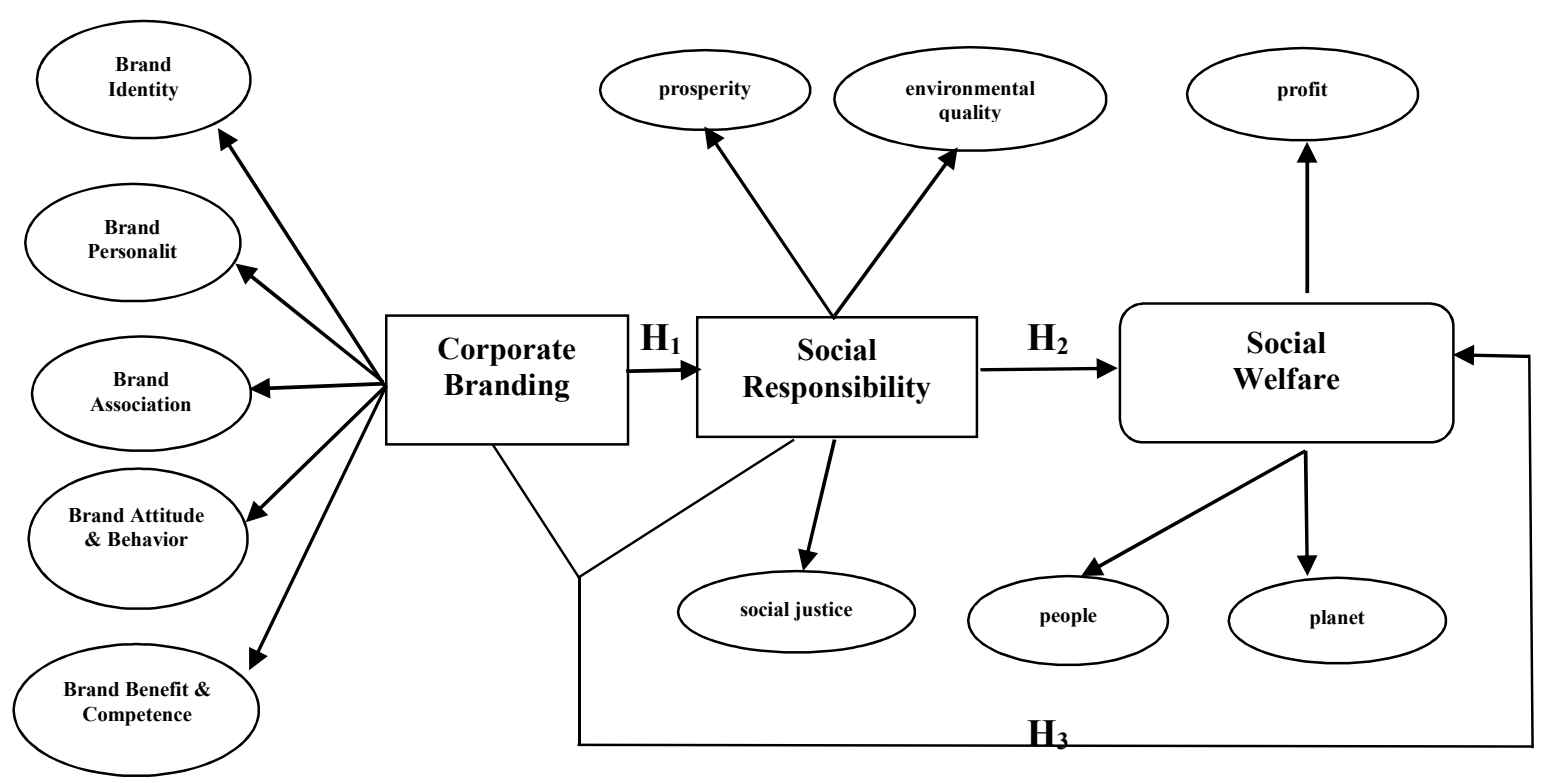

Fig 2.1 Thinking Framework

\section{Method}

This research method describes at least three important components including research design, population and sample and analysis techniques.

\section{1. Research design}

This research is a hypothesis testing research and intends to analyze how far the implementation of Corporate Branding (X1) and Social Responsibility (X2) on increasing in Social Welfare $(\mathrm{Y})$. Thus, this research tries to gather facts and data related to the variables of concern in this research. To answer the research problem, quantitative research methods are based on reality/symptoms/ phenomena, can be classified, relatively fixed, concrete, observable, measurable and causality relationships. This research is motivated by a visible increase on the economic level in North Bekasi region. The formulation of the problem from the identification results will guide the research to find answers to the truth of the problem faced, as for the temporary answer from the problem statement explained in the hypothesis, the hypothesis as a temporary answer to the problem statement will be verified empirically based on data that collect from the field, therefore data collection at the population level and sample is necessary, to collect data, this research uses questionnaire forms given to employees (100 employees) of PT. Summarecon Agung Tbk (cq. Summarecon Bekasi), study of literature and internet, so the instruments can be trusted for validity and reliability tests, that can be used to measure the variables that have been determined to be studied then. Then the collected data is analyzed to answer the formulation of the problem and the proposed hypothesis, using statistics processed through SPSS version 22 program. 


\section{2. Population and Samples}

Population is a generalization area consisting of objects that have certain qualities and characteristics applied by researchers to be studied and drawn conclusions then [13]. The number of employees from PT. Summarecon Agung Tbk Bekasi, who domiciled in Bekasi area, is 134 people. The sample of this research used Slovin formula as equal to 100 respondents [14].

\section{3. Analysis Techniques}

Analysis Methods of the data used in this research are validity Test, Reliability Test, Multicollinierity Test, Heteroscedasticity Test, Normality Test (Kolmogorov-Smirnov Test), Multiple Linear Regression Analysis Test, Hypothesis test ( F Test and t Test), and Coefficient of Hypothesis Determination $\left(\mathrm{r}^{2}\right)$.

\section{Result and Analysis}

\section{1 Research Results}

The purpose of this research is to determine how far their implementation of Corporate Branding and Social Responsibility of PT. Summarecon Agung Tbk (cq. Summarecon Bekasi) on the improvement of Social Welfare in Bekasi City, especially North Bekasi area, by collecting data through questionnaires distributed to 100 employees from 26 to 30 November 2018 at PT. Summarecon Agung Tbk, Summarecon Bekasi unit. The analysis method used in this research is the analysis of Validity, Reliability, Multicollinearity, Heteroscedasticity, Normality (Kolmogorov-Smirnov) test and multiple linear regression analysis by examining $t$ partially and F simultaneously test (Hypothesis Test) and the Determination Coefficient $\left(\mathrm{r}^{2}\right)$ test.

\section{2 Analysis}

Validity test. Validity test is used to measure the validity of a questionnaire. Validity test is done by using the correlation analysis method. The conclusion from the output of all indicators showed significant results $(0.000<0.05)$, so it can be concluded that each indicator is Valid.

Table 4.1 Validity Test of the Corporate Branding, Social Responsibilty and Social Welfare Variables

With $\mathrm{n}=100$, the calculation of $\mathrm{df}=100-2=98$, so $\mathrm{r}$ table is 0.1966

\begin{tabular}{lcll}
\hline \multicolumn{1}{c}{ Variables } & R Calculation & R Table & Result \\
\hline Corporate Branding & 0.759 & 0.1966 & Valid \\
Social Responsibility & 0.830 & 0.1966 & Valid \\
Social Welfare & 0.750 & 0.1966 & Valid \\
\hline Source : Data processed from SPSS & &
\end{tabular}

Reliability Test. This test is conducted to determine the consistency of the results of the respondent's responses. The table below presents the results of reliability test for the Corporate 
Branding, Social Responsibility and Social Welfare variables. The results of the reliability test explains the value of Cronbach's Alpha for each variable is greater than 0.60 , it can be concluded that the measuring instrument is Reliable.

Table 4.2 Reliability Test of The Corporate Branding, Social Responsibility and Social Welfare Variables

\begin{tabular}{cccc}
\hline Items & Cronbach's Alpha & Standard & Result \\
\hline Corporate Branding & 0.875 & 0.60 & Reliable \\
Social Responsibility & 0.774 & 0.60 & Reliable \\
Social Welfare & 0.805 & 0.60 & Reliable \\
\hline
\end{tabular}

Source : Data processed from SPSS

Multicolinearity Test. Multicolinearity test aims to examine whether the regression model finds a correlation among independent variables. A good regression model should not have a correlation among independent variables. Multicolinearity can be seen from the value of Variance Inflation Factor (VIF). If the VIF value is $<10$, it can be concluded that there is no multicolinearity among the independent variables in the regression model in this research. The results of the analysis shows all the independent variables have a Variance Inflation Factor (VIF) value $<10$. So it can be concluded that there is No Multicolinearity among independent variables in the regression model.

Table 4.3 Multicolinierity Test

\begin{tabular}{ccc}
\hline \multirow{2}{*}{ Model } & \multicolumn{2}{c}{ Collinearity Statistics } \\
\cline { 2 - 3 } & Tolerance & VIF \\
\cline { 2 - 3 } Corporate Branding & 0.422 & 2.372 \\
Social Responsibility & 0.422 & 2.372 \\
\hline
\end{tabular}

Source : Data processed from SPSS

Heteroscedasticity Test. Heteroscedasticity tests can be done with scatterplot graphs. Through graphic analysis, a regression model is considered no heteroscedasticity occured if the points spread randomly and do not form a certain clear pattern and spread above or below the zero on the $\mathrm{Y}$ axis. To find out whether there are symptoms of heteroscedasticity, can be done by using a heteroscedasticity scatterplot graphs between the predictive value of the dependent variable and the independent variables. From the scatterplot above the dots are scattered randomly and spread both above and below 0 (zero) and the Y axis. It can be concluded that there is No Heteroscedasticity (Homoscedasticity) in the regression model, so the regression model is feasible used in the test. 


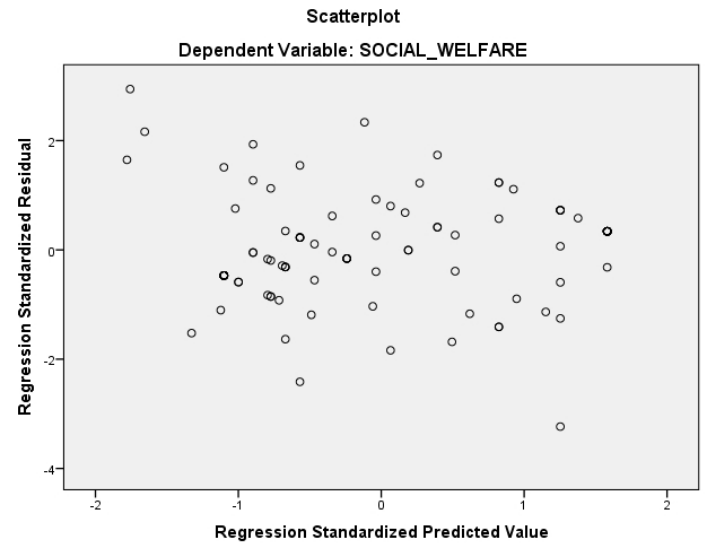

Fig 4.1 Heteroscedasticity Test

Normality Test (Kolmogorov-Smirnov Test). The normality test aims to test whether in the regression model, the disturbing or residual variables have a normal distribution or not. The result shows that the variable value Asymptot Significancy (2-tailed) of Corporate Branding (0.000), Social Responsibility (0.000), and Social Welfare (0.000) is smaller than $\alpha$ $=0.05$, so the variable is Abnormal and has a significant influence.

Table 4.4 Normality Test

\begin{tabular}{cccc}
\hline & Corporate Branding & Social Responsibility & Social Welfare \\
\hline Asymp. Sig. (2-tailed) & $0.000^{\mathrm{c}}$ & $0.000^{\mathrm{c}}$ & $0.000^{\mathrm{c}}$ \\
\hline
\end{tabular}

Source : Data processed from SPSS

Multiple Linear Regression Analysis. Below is presented the results of multiple linear regression equations analysis :

Social Welfare $=5.617+0.182$ Corporate Branding +0.584 Social Responsibility $+\mathrm{e}$ Regression equation models can be interpreted as follows:

a. The constant value of 5.617 states that the Social Welfare is 5.617 if the Corporate Branding variable, Social Responsibility is considered constant or equal to zero.

b. The regression coefficient of Corporate Branding is 0.182, means if the value of Corporate Branding increases equal to one unit, then Social Welfare will increase equal to 0.182 .

c. The regression coefficient of Social Responsibility variable is 0.584 , means if the value of Social Responsibility increases equal to one unit, then Social Welfare will increase equal to 0.584 .

Table 4.5 Multiple Linear Regression Analysis

\begin{tabular}{cc}
\hline Model & B Coefficients \\
\hline Constant & 5.617 \\
Corporate Branding & 0.182 \\
Social Responsibility & 0.584 \\
\hline
\end{tabular}

Source : Data processed from SPSS 


\section{Hypothesis Test}

Simultaneous Hypothesis (F-Test). In this research, the F test is used to determine the significance level of the Corporate Branding and Social Responsibility variables simultaneously influenced on Social Welfare. The results of statistical calculations show the value of $F_{\text {count }}=68.306>F_{\text {table }}=3.09$ and a significance value $\quad 0.000<0.05$, this indicates the Corporate Branding and Social Responsibility are simultaneously and significantly influence Social Welfare.

Table 4.6 Simultaneous Hypothesis (F-Test)

\begin{tabular}{ccc}
\hline Model & F test & Significancy \\
\hline Regresssion & 68.306 & $0.000^{\mathrm{b}}$ \\
\hline Source : Data processed from SPSS &
\end{tabular}

Partial Significant Test (t-Test). To test the significance of the regression model for each variable partially can be obtained using the t-test which can be seen in the following table:

a. The partial test results of hypothesis for the Corporate Branding variable show a value of $t_{\text {count }}=2.059>t_{\text {table }}=1.98$ with a significance value $0.042<0.05$, so it can be concluded that Corporate Branding variable has a positive and significant effect on Social Welfare.

b. The partial test results of hypothesis for Social Responsibility variables show a value of $t_{\text {count }}=5.904>t_{\text {table }}=1.98$ with a significance value $0.000<0.05$, so it can be concluded that Social Responsibility variable has a positive and significant effect on Social Welfare.

Table 4.7 Partial Significant (t-Test)

\begin{tabular}{ccc}
\hline Model & T test & Significancy \\
\hline Constant & 2.996 & 0.003 \\
Corporate Branding & 2.059 & 0.042 \\
Social Responsibility & 5.904 & 0.000 \\
\hline
\end{tabular}

Determination Coefficient Test $\left(\mathrm{r}^{2}\right)$. This coefficient of determination is used to determine how far the independent variables influence the dependent variable. The coefficient of determination is determined by the value of $\mathrm{R}$ square. Based on the table above, it can be seen that the coefficient of determination obtained is 0.585 or in other words Corporate Branding and Social Responsibility have significant influence on Social Welfare 58.5\%. While the rest $(100 \%-58.5 \%=41.5 \%)$ is influenced by other variables outside of this regression model.

Table 4.8 Determination Coefficient Test $\left(\mathrm{R}^{2}\right)$

\begin{tabular}{cc}
\hline Model & R Square \\
\hline 1 & 0.585 \\
\hline
\end{tabular}




\section{Conclusion}

This research aims to find out how far the implementation of Corporate Branding and Social Responsibility of PT. Summarecon Agung Tbk (cq. Summarecon Bekasi) towards Social Welfare on communities in the North Bekasi area. From the results of the research's analysa, the researcher can conclude the results of the research as follows: (1) Variable Corporate Branding $\left(\mathrm{X}_{1}\right)$ has a positive and significant effect on Social Welfare $(\mathrm{Y})$ and also (2) Social Responsility $\left(\mathrm{X}_{2}\right)$ variable has a positive and significant effect on Social Welfare (Y).

\section{References}

[1] J. Creswell, Educational research: Planning, conducting, and evaluating quantitative and qualitative research. Upper Saddle River. 2005.

[2] S. Helms, Reputation Management, First edit. Springer, 2011.

[3] K. L. Keller, "Branding Perspectives on Social Marketing.," Adv. Consum. Res., vol. 25, no. 1, pp. 299-302, 1998.

[4] A. Prastowo, Metode Penelitian Kualitatif dalam Perspektif Rancangan Penelitian. Ar-Ruzz Media Yogyakarta, 2011.

[5] A. Lako, Dekonstruksi CSR dan Reformasi Paradigma Bisnis dan Akuntansi. Erlangga Jakarta, 2011.

[6] A. Fahrudin, "Psychosocial Reaction and Trauma After a Natural Disaster: The Role of Coping Behavior," Asian Soc. Work Policy Rev., vol. 6, no. 3, pp. 192-202, 2012.

[7] N. Hadi, Corporate Social Responsibility, Edisi pert. Graha Ilmu Yogyakarta, 2011.

[8] B. Ramasamy and M. Yeung, "Chinese consumers' perception of corporate social responsibility (CSR)," J. Bus. Ethics, vol. 88, no. SUPPL. 1, pp. 119-132, 2009.

[9] M. C. Branco and L. L. Rodrigues, "Corporate social responsibility and resourcebased perspectives," J. Bus. Ethics, vol. 69, no. 2, pp. 111-132, 2006.

[10] K. L. Keller, "Building strong brands in a modern marketing communications environment," in The Evolution of Integrated Marketing Communications: The Customer-Driven Marketplace, 2013, pp. 65-82.

[11] J. Elkington, "Cannibals with forks. The triple bottom line of 21st century business," New Soc. Publ., no. April, p. 407, 1998.

[12] E. Suharto, "Peran Perlindungan Sosial Dalam Mengatasi Kemiskinan Di Indonesia: Studi Kasus Program Keluarga Harapan," Sosiohumaniora, vol. 17, no. 1, 2015.

[13] Sugiyono, "Populasi dan sampel," Popul. dan sampel, vol. 5, no. 1976, pp. 265-288, 2010.

[14] Sugiyono, "Total sampling," 2007. . 